\title{
REDOX STATUS DURING PREGNANCY, PERI-PARTURITION AND POST CALVING-FIRST INSEMINATION PERIOD IN FERISIAN COWS
}

\author{
A.K. Kadoom and M.A.A El-Henawy \\ Animal production research institute, Agriculture Research Center, Ministry of Agriculture, Egypt
}

\section{SUMMARY}

A total of fifteen late pregnant Holstein Friesian cows with different parities were selected 3-6 weeks before calving. 231 Jugular Blood samples were collected weekly along 18 weeks for serum separation. Serum Hydrogen peroxide $\mathrm{H}_{2} \mathrm{O}_{2}$ ), Malondialdehyde (MDA) and Total antioxidant capacity (TAC) were measured colorimetrically. Both $\mathrm{H}_{2} \mathrm{O}_{2}$ and $M D A$ averages were increased gradually and reached the peak $(P<0.01)$ one week before calving, TAC averages were dropped at the $5^{\text {th }}$ week and increased gradually to peak again at the last week before calving and fluctuated with a peak $(P<0.01)$ at the $10^{\text {th }}$ week post- calving. The Parity and cow effect was significant for $\left(\mathrm{H}_{2} \mathrm{O}_{2} \& \mathrm{MDA}\right)$ and TAC averages, $P<0.05$ and $p<0.01$ respectively. Cows having retained placenta were accompanied by high $\mathrm{H}_{2} \mathrm{O}_{2}(323.9 \pm 19.69 \mu \mathrm{mol} / \mathrm{L})$ and low serum TAC $(1790.8 \pm 12.32 \mathrm{mmol} / \mathrm{L})$ concentration, $(P<0.01)$. Cows not bred after calving showed high $(\mathrm{P}<0.01) \mathrm{H}_{2} \mathrm{O}_{2}(292.6 \pm 11.46 \mu \mathrm{mol} / \mathrm{L})$ and low TAC averages $(1890.1 \pm 17.33 \mathrm{mmol} / \mathrm{L})$ comparing to cows that bred either became pregnant or not.

The study declared that the addition of antioxidant to the ration or the injection of vitamin E may play a role to overcome the redox status of the cows under investigation.

Keywords: Frisian, antioxidant, redox status, calving, insemination period

\section{INTRODUCTION}

Oxidation reactions are an essential part of normal metabolism as oxygen is the ultimate electron acceptor in the electron flow system that produces ATP (Davies, 1993). Reactive oxygen species (ROS) play different positive roles in vivo, being involved in energy production needed for phagocytosis, cell growth and intercellular signaling regulation. Problems may arise when electron flow and energy production become uncoupled so that oxygen free radicals (ROS) are produced (Nohl et al., 2005). The ROS may be highly damaging, as they can attack biological macromolecules, namely, lipids, proteins and DNA inducing oxidation and cause membrane damage, enzyme inactivation and DNA damage (Halliwell and Gutteridge 1999 and Valko et al., 2004).

Antioxidant capacity system consists of two mechanisms: enzymatic and non enzymatic mechanisms those scavenger free radicals. In cattle, characteristics of these mechanisms depend mainly on the nutritional status of antioxidant minerals especially copper, zinc, iron, selenium, silicon and manganese (Kleczkowski et al., 2003). Polyphenols can stimulate antioxidant transcription and detoxification defense systems through antioxidant responsive elements, ARE (Masella et al., 2005)

Redox studies in cattle have been sporadic and mainly with mastitis, pneumonia, and retained placenta. Recently, studies have been focused on metabolic diseases that affect dairy cows during the peripartum period. Numerous and rapidly evolving methodologies for evaluating oxidative stress are available to researchers and clinicians, each with their own distinct advantages and disadvantages. Differences in models and methodologies make it difficult to make meaningful comparisons, even for studies that seem quite similar superficially (Pietro Celi, 2010).

Pregnancy was associated with decreased total antioxidant capacity (TAC) and uric acid in the first trimester, which gradually increased during pregnancy, reaching normal values during postpartum period (Toescu et al., 2002). In cattle, the peri-parturient period is especially critical for health and subsequent reproductive performance (Erisir et al., 2006).

The aim of this study was to shed more light on the occurrence of oxidative stress in close up period of Friesian cows and follow it till the post-calving first insemination (PCFI) by the determination of Hydrogen peroxide (H2O2) as free radical indicator and Malondialdehyde (MDA) levels as lipid peroxide indicator and total antioxidant capacity status (TAC).

\section{MATERIALS AND METHODS}

Animals:

A total of fifteen late pregnant dry Friesian cows with different parities averaging three - six weeks before calving were selected. Cows closely before calving were fed corn silage(5 $\mathrm{kg}$ ), rice straw (four $\mathrm{kg}$ ), hay (two $\mathrm{kg}$ ) and five $\mathrm{kg}$ concentrate (consists of $34 \%$ un -decorticated cotton seed cake, $24 \%$ wheat bran, $22 \%$ yellow 
corn, $10 \%$ rice bran, $5 \%$ line seed cake, $2 \%$ molasses, $2 \%$ lime stone and $1 \%$ common salt). After calving all cows were fed $12 \mathrm{kgs}$ corn silage, four $\mathrm{kg}$ rice straw, three $\mathrm{kg}$ hay and eight $\mathrm{kg}$ concentrate.

Cow had delayed expulsion of fetal membranes $>8 \mathrm{hrs}$ after calving was counted as a retained placental cow and was treated with the protocol applied in the farm as application of systemic and intra uterine antibiotics pessaries, injection of prostaglandin $\mathrm{F}_{2 \infty}$ and oxytocin before milking on the second day after calving and followed up till complete recovery. All cows examined at day 35 post-calving to evaluate their reproductive status ( uterine involution, Type of vaginal discharges if it is present, ovarian activity) and then followed up for heat detection and breeding with maximum 11 weeks postpartum.

\section{Blood sampling:}

Jugular Blood samples were collected weekly and let for clotting. Serum was separated by centrifugation at $4000 \mathrm{rpm}$ for 10 minutes and then frozen and preserved at $-40{ }^{\circ} \mathrm{c}$ till the chemical analysis was done.

\section{Chemical analysis:}

- Hydrogen peroxide was measured colorimetrically at $510 \mathrm{~nm}$ using Biodignostic kits, Cairo, Egypt, Cat. No. HP 25(Aedi H. 1984).

- Malondialdehyde (MDA) was measured colorimetrically at $534 \mathrm{~nm}$ using Biodignostic kits, Cairo, Egypt, Cat. No. MDA 2529 (Satoh K.1978 and ohkawa et al., 1979).

- Total antioxidant were measured colorimetrically using Biodignostic kits, Cairo, Egypt, Cat. No.TA 2513 at 505nm (Koracevic et al., 2001).

All the colorimetric assays were quantified using spectrophotometer

\section{Statistical analysis:}

It was carried out using SPSS version 17. Results were expressed as mean \pm SEM. Analysis of variance (one way ANOVA) followed by Duncan' test were used to determine whether there were significant differences among the groups. Differences were considered significant when $P$ values were less than 0.05 .

\section{RESULTS AND DISCUSSION}

Weekly averages of fifteen blood serum samples along 18 weeks revealed that, both $\mathrm{H}_{2} \mathrm{O}_{2}$ and MDA averages had a clear trend, it is increased gradually and reached the peak $(\mathrm{P}<0.01)$ one week before calving and then declined again but not reached the bottom level again (Figures 1\&2,).

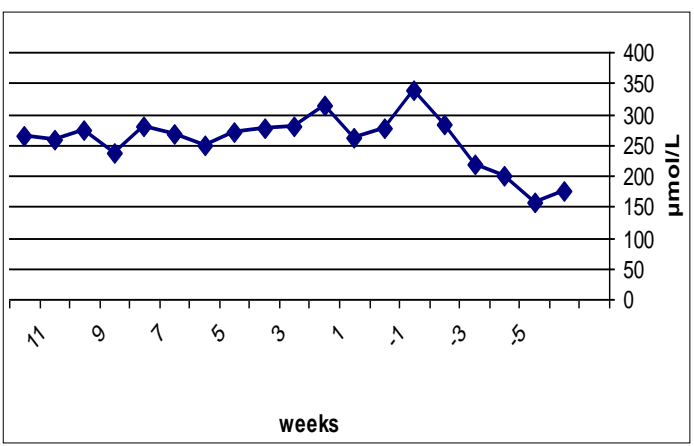

Fig. 1. Pre and post calving means of $\mathrm{H}_{2} \mathrm{O}_{2}$ in Frisian cows

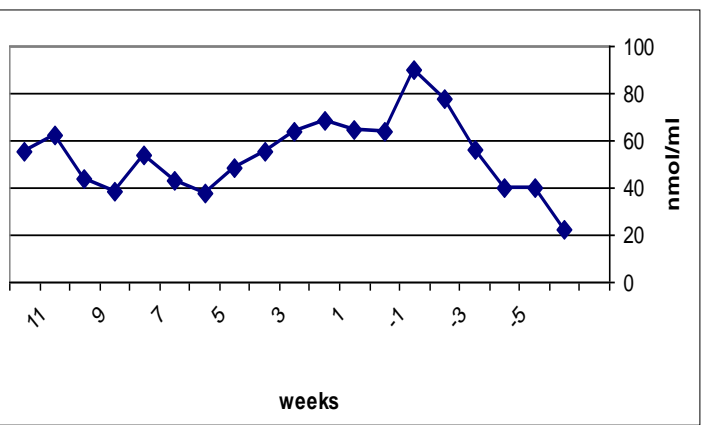

Fig. 2. Pre and post calving means of MDA in Frisian cows

On the other hand, TAC averages had a clear trend pre-calving, it is dropped at the $5^{\text {th }}$ week and increased gradually to the peak again on the last week before calving and then declined and fluctuated with a peak $(\mathrm{P}<0.01)$ at the $10^{\text {th }}$ week post- calving (Figure 3). Castillo et al. (2005) noticed no trend for plasma MDA level in close cows 10 weeks before calving till two weeks after calving. The TAC averages had a trend precalving. Castillo et al. (2005) noticed the same TAC level trend, it was peaking $(\mathrm{P}<0.05)$ one week after calving and then declined. Kandofer et al. (2010) added that TAC differs $(\mathrm{P}<0.05)$ with time pre and postpartum. The maximum level of peroxidation (MDA level) was observed in the first week post partum (pp) comparing with its level in late lactation (Adela et al., 2006). The oxidative stress was increased in cows after parturition under hot climatic condition (Tanaka et al., 2011), while, Bernabucci et al. (2002) concluded that heat stress effect on oxidative status in transition cows doesn't clear and cows with pre-calving high body condition score (BCS) and get higher BCS losses are more sensitive to oxidative stress (Bernabucci et al., 2005) with high B-hydroxy butyric acid (BHBA) and non-esterified fatty acids (NEFA). On contrast, Gaal et al. (20o6) reported that no significant differences were found between pre-calving, calving and postcalving means of both MDA and TAC. 


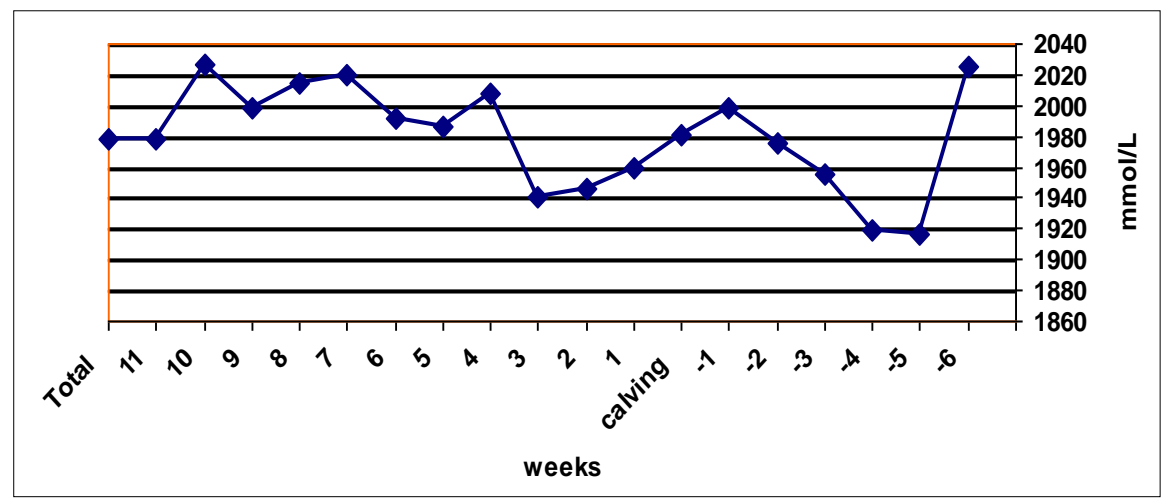

Fig. 3. pre and post calving means of TAC in Frisian cows

Table 1. Serum $\mathrm{H}_{2} \mathrm{O}_{2}$, MDA and TAC among cows pre and post-calving

\begin{tabular}{|c|c|c|c|c|c|c|c|}
\hline \multirow{2}{*}{$\begin{array}{l}\text { Cow } \\
\text { number }\end{array}$} & \multirow[t]{2}{*}{ Sample N } & \multicolumn{2}{|c|}{$\mathrm{H}_{2} \mathrm{O}_{2}(\mu \mathrm{mol} / \mathrm{L})$} & \multicolumn{2}{|c|}{ MDA $(\mathrm{nmol} / \mathrm{ml})$} & \multicolumn{2}{|c|}{ TAC $(\mathrm{mmol} / \mathrm{L})$} \\
\hline & & Average & SEM & Average & SEM & Average & SEM \\
\hline 4053 & 14 & $247.2^{b}$ & 35.73 & $45.7^{\mathrm{c}^{* *}}$ & 6.43 & $2202.0^{\mathrm{b}}$ & 15.51 \\
\hline 4074 & 14 & $289.6^{\mathrm{a}}$ & 26.95 & $60.1^{\mathrm{b}}$ & 6.38 & $1836.4^{\mathrm{c}}$ & 12.66 \\
\hline 4083 & 18 & $241.6^{\mathrm{b}}$ & 29.06 & $54.5^{\mathrm{b}}$ & 8.50 & $1871.7^{\mathrm{c}}$ & 20.36 \\
\hline 4132 & 14 & $242.6^{\mathrm{b}}$ & 26.73 & $53.2^{\mathrm{b}}$ & 6.94 & $2210.7^{\mathrm{a} * *}$ & 16.51 \\
\hline 4200 & 15 & $123.0^{\mathrm{c} * *}$ & 18.98 & $51.6^{\mathrm{b}}$ & 5.44 & $2220.2^{\mathrm{a} * *}$ & 15.53 \\
\hline 4238 & 17 & $268.2^{\mathrm{a}}$ & 25.35 & $53.1^{\mathrm{b}}$ & 8.88 & $1844.3^{c}$ & 16.10 \\
\hline 4341 & 14 & $166.9^{\mathrm{c} * *}$ & 29.00 & $59.1^{\mathrm{b}}$ & 9.96 & $2087.0^{\mathrm{b}}$ & 18.41 \\
\hline 4422 & 12 & $291.7^{\mathrm{a}}$ & 24.44 & $48.5^{\mathrm{c} * *}$ & 5.09 & $1859.0^{\mathrm{c}}$ & 11.38 \\
\hline 4437 & 15 & $337.8^{\mathrm{a}}$ & 44.66 & $72.7^{\mathrm{a}^{* *}}$ & 6.31 & $2076.5^{\mathrm{b}}$ & 19.92 \\
\hline 4461 & 15 & $349.2^{\mathrm{a}}$ & 35.74 & $73.4^{\mathrm{a} * *}$ & 7.29 & $1778.7^{\mathrm{d}^{\mathrm{*} *}}$ & 21.78 \\
\hline 4463 & 18 & $292.2^{\mathrm{a}}$ & 38.68 & $51.1^{\mathrm{b}}$ & 7.73 & $2144.0^{\mathrm{b}}$ & 11.61 \\
\hline 4467 & 18 & $326.0^{\mathrm{a}}$ & 33.20 & $55.9^{\mathrm{b}}$ & 6.40 & $1802.9^{\mathrm{d} * *}$ & 11.54 \\
\hline 4476 & 17 & $257.8^{\mathrm{b}}$ & 25.18 & $57.1^{\mathrm{b}}$ & 7.14 & $1858.7^{\mathrm{c}}$ & 12.59 \\
\hline 4483 & 18 & $248.1^{\mathrm{b}}$ & 16.58 & $48.8^{\mathrm{b}}$ & 8.05 & $1857.7^{\mathrm{c}}$ & 11.25 \\
\hline 4508 & 12 & $289.2^{\mathrm{a}}$ & 32.31 & $50.4^{\mathrm{b}}$ & 8.26 & & \\
\hline Total & 231 & 265.2 & 8.53 & 55.7 & 1.94 & 1978.7 & 12.52 \\
\hline
\end{tabular}

Averages marked with $a, b, c \& d$ differ at $p<0.05$ within the same column

**means differ at $\mathrm{P}<0.01$ within the same column.

Table 2. Serum concentration of $\mathrm{H}_{2} \mathrm{O}_{2}, \mathrm{MDA}$ and TAC pre and post-calving in cows in relation to Parity

\begin{tabular}{|c|c|c|c|c|c|c|c|}
\hline \multirow{2}{*}{ Parity } & \multirow{2}{*}{ Sample N } & \multicolumn{2}{|c|}{ H2O2 $(\mu \mathrm{mol} / \mathrm{L})$} & \multicolumn{2}{|c|}{ MDA (nmol/ml) } & \multicolumn{2}{|c|}{ TAC (mmol/L) } \\
\hline & & Mean & $\mathrm{SE}$ & Mean & SE & Mean & SE \\
\hline $1^{\text {st }}$ lactation & 113 & $297.9^{b}$ & 11.39 & 57.3 & 2.67 & $1922.6^{b}$ & 16.57 \\
\hline $2^{\text {nd }}$ Lactation & 26 & $224.5^{\mathrm{a}}$ & 22.62 & 54.2 & 5.84 & $1986.7^{\mathrm{a}}$ & 25.69 \\
\hline $3^{\text {rd }}$ Lactation & 92 & $232.8^{\mathrm{a}}$ & 11.26 & 51.8 & 2.83 & $2030.7^{a}$ & 20.62 \\
\hline Total & 231 & 264.6 & 7.87 & 54.7 & 1.84 & 1977.9 & 12.48 \\
\hline
\end{tabular}

Averages marked with a \& $\mathrm{b}$ in the same column are different at $\mathrm{P}<0.05$

Table (1) shows that individual cow effect was significantly clear for $\mathrm{H}_{2} \mathrm{O}_{2}$, MDA and TAC averages where parity has a significant effect on serum $\mathrm{H}_{2} \mathrm{O}_{2}$ mean $(297.9 \pm 11.39) \mu \mathrm{mol} / \mathrm{L}$ which was high $(\mathrm{P}<0.05)$ in the first lactation cows while TAC concentration was low $(1922.6 \pm 16.57) \mathrm{mmol} / \mathrm{L}$ comparing to the $2^{\text {nd }}$ and $>2$ lactations. The serum MDA level was decreased insignificantly with the increase of the lactation number as shown in Table (2).

As shown in Table (3), cows had got retained placenta were accompanied by significant high $\mathrm{H}_{2} \mathrm{O}_{2}(323.9 \pm 19.69 \mu \mathrm{mol} / \mathrm{L})$ and low serum TAC $(1790.8 \pm 12.32 \mathrm{mmol} / \mathrm{L})$ concentration $(\mathrm{P}<0.01)$ as shown in table-4, while, MDA were insignificantly high in ROP cows $(60.2 \pm 4.31$ $\mathrm{nmol} / \mathrm{ml})$ than normal cows (54.6 \pm 2.17 $\mathrm{nmol} / \mathrm{ml}$ ). Erisir et al. ( 2006) and Yildiz et al. (2011) agreed that serum or plasma MDA concentration in ROP cows did not significantly altered from normal one while, the erythrocyte MDA markedly increased in Dystocia cow compared with eutocia cow (Yildiz et al., 2011 ). On contrast, Kandofer et al. (2010) found that blood means of oxidants and antioxidants did not differ among animals with or without retained placenta. The mean MDA concentration in the acute puerperal metritis was significantly higher in the diseased cows than in controls. Hanafi et al. (2008) noticed that MDA was significantly 
high $(\mathrm{P}<0.001)$ in buffalo cows exhibited endometeritis while, TAC was low. These results demonstrate the occurrence of an oxidative stress in cows with acute puerperal metritis which is exacerbated throughout antioxidant overutilization (Kizil et al., 2010 and Heidarpour et al., 2012). After successful treatment for clinical endometritis, serum MDA concentrations have also significantly decreased and TAS values were increased when treatment was successful in subclinically and clinically affected cows 7 days after (Heidarpour et al., 2012).

Cows that did not exhibit estrus signs and not bred after calving showed high $(\mathrm{P}<0.01) \mathrm{H}_{2} \mathrm{O}_{2}$ (292.6 \pm 11.46$) \mu \mathrm{mol} / \mathrm{L}$ and low TAC averages $(1890.1 \pm 17.33) \mathrm{mmol} / \mathrm{L}$ comparing to cows came in heat and bred either became pregnant or not as shown in table-4. In agreement with this, Ali et al. (2014) noticed that MDA levels of repeat breeder and anestrous cows was high $(\mathrm{P}<0.01)$ than those came in heat. Excess oxidation, however, causes oxidative stress, resulting in the dysfunction of reproductive processes and antioxidant that reduce the levels of ROS maintain the quality of gametes and support reproduction (Fujii et al., 2005).

Lastly, we concluded that fine addition of antioxidant as copper, zinc and selenium to the ration or by injection of vitamin $\mathrm{E}$ may play a role to overcome the oxidant stress and might help in improving the post-calving reproductive status of the animal.

Table 3. Serum concentration of $\mathrm{H}_{2} \mathrm{O}_{2}$, MDA and TAC pre and post-calving in cows in relation to the incidence of retained placenta (ROP)

\begin{tabular}{llllllll}
\hline \multirow{2}{*}{ ROP } & \multirow{2}{*}{ Sample $\mathbf{N}$} & \multicolumn{2}{c}{$\mathbf{H}_{\mathbf{2}} \mathbf{O}_{\mathbf{2}}(\boldsymbol{\mu} \mathbf{m o l} / \mathbf{L})$} & \multicolumn{2}{c}{ MDA $(\mathbf{n m o l} / \mathbf{m l})$} & \multicolumn{2}{c}{ TAO $(\mathbf{m m o l} / \mathbf{L})$} \\
\cline { 2 - 7 } & & Mean & SE & Mean & SE & Mean & SE \\
\hline nil & 186 & 250.9 & 9.19 & 54.6 & 2.17 & $2012.7^{* *}$ & 12.97 \\
ROP & 45 & $323.9^{* *}$ & 19.69 & 60.2 & 4.31 & 1790.8 & 12.32 \\
Total & $\mathbf{2 3 1}$ & $\mathbf{2 6 5 . 2}$ & $\mathbf{8 . 5 3}$ & $\mathbf{5 5 . 7}$ & $\mathbf{1 . 9 4}$ & $\mathbf{1 9 7 8 . 7}$ & $\mathbf{1 2 . 5 2}$ \\
\hline
\end{tabular}

** The average means in the same column significantly differ at $\mathrm{P}<0.01$

Table 4. Serum concentration of $\mathrm{H}_{2} \mathrm{O}_{2}, \mathrm{MDA}$ and TAC pre and post-calving in cows in relation to post partum breeding

\begin{tabular}{|c|c|c|c|c|c|c|c|}
\hline \multirow{2}{*}{$\begin{array}{l}\text { Post } \\
\text { calving } \\
\text { status }\end{array}$} & \multirow{2}{*}{$\begin{array}{c}\text { Sample } \\
\mathbf{N}\end{array}$} & \multicolumn{2}{|c|}{$\mathrm{H}_{2} \mathrm{O}_{2}(\mu \mathrm{mol} / \mathrm{L})$} & \multicolumn{2}{|c|}{ MDA (nmol/ml) } & \multicolumn{2}{|c|}{ TAO (mmol/L) } \\
\hline & & Mean & SE & Mean & $\mathrm{SE}$ & Mean & SE \\
\hline Not Bred & 100 & $292.6^{\mathrm{a}}$ & 11.46 & 55.2 & 2.86 & $1890.1^{b}$ & 17.33 \\
\hline Repeat bred & 105 & 246.4 & 11.76 & 54.5 & 2.67 & $2037.5^{\mathrm{a}}$ & 17.85 \\
\hline $\begin{array}{l}\text { Bred \& get } \\
\text { pregnant }\end{array}$ & 26 & $224.5^{\mathrm{b}}$ & 22.62 & 54.2 & 5.84 & $1986.7^{\mathrm{a}}$ & 25.69 \\
\hline Total & 231 & 264.6 & 7.87 & 54.7 & 1.84 & 1977.9 & 12.48 \\
\hline
\end{tabular}

a \& $\mathrm{b}$ differ at $\mathrm{P}<0.01$ within the same column.

\section{REFERENCES}

Adela, P., D. Zinveliu, P R.AI. op, S. Anderi and E. Kiss, 2006. Antioxidant status in dairy cows during lactation. Buletin USAMV-CN. 63: $130-135$

Aebi, H. 1984: Methods Enzymol 105, 121-126

Ali F., Lodhi L.A., Hussain R. and Sufyan M., 2014. Oxidative status and some serum macro minerals during estrus, anestrous and repeat breeding in Cholistani cattle. Pakistan veterinary journal. ISSN: 02538318(RPRINT), 2074-7764

Bernabucci, U., B. Ronchi, N. Lacetera and Nardone A., 2002. Markers of oxidative status $\mathrm{n}$ plasma and erythrocytes of transition dairy cows during hot season. J. Dairy Sci. 85: 2173-2179

Bernabucci, U., B. Ronchi, N. Lacetera and A. Nardone, 2005. Influence of body Score on relationships between metabolic status and oxidative stress in periparturient dairy cows. J. Dairy Sci.88:2017-2026
Castillo, C., J. Hernandez, M. Bravo, M. LopezAlonso, Pereira V and J. L. Benedito, 2005. Oxidative and early status during the pregnancy and early lactation in dairy cows. The Veterinary Journal 169: 286-292

Davies, K.J., 1993. Oxidative stress: the paradox of aerobic life. Biochem Soc Symp; 6: 1-31

De Smet, S., N.Wullepit, M. Ntawubizi, B. Beerda , R.F. Veerkamp and K . Raes, 2006. Veerkamp \& K. Raes $57^{\text {th }}$ EAAP Annual Meeting, Antalya, 17-20

Erisir, M., Y. Akar, S.Y. Gurgose and M.Yuksel, 2006. Changes I plasma malondialdehyde concentration and some erythrocyte antioxidant enzyme in cows with prolasus uteri, caesarean section, and retained placenta. Revue Med. Vet., 157.2: 80-83

Fujii, J., Y. Iuchi and F. Okada, 2005. Fundamental roles of reactive oxygen species and protective mechanisms in the female reproductive system. Reprod. Bio. and Endo., 3: 43 doi: 10.1186/1477-7827-3-43 
Gaal, T., P. Ribiczyne, K. Stadler, J. Jakus, J. Reiczigel, Kover Pal, M. Mezes and L. Sumeghy, 2006. Free radicals, lipid peroxidation and the antioxidant system in the blood of cows and new born calves around calving. Comparative Biochemistry and Physiology, Part B. 143: 391-396

Halliwell B. and Gutteridge JMC, 1999. Free radicals in biology and medicine. $3^{\text {rd }}$ edition .Oxford: Clarendon press; chapter 4.

Hanafi Emtenan M., Ahmed W.M., AbdElMoez Sherein I., 2008. Effect of clinical endometritis on ovarian activity and oxidative stress status in Egyptian buffalocows. Am.Euras.J.Ag .ric. \& Environ.Sci. 4(5): 530-536

Heidarpour M., Mohri M., Fallah-Rad A.H., Dehghan Shahreza F. and Mohammad M., 2012. Oxidative stress and trace elements before and after treatment in dairy cows with clinical and subclinical endometritis Revue Méd. Vét. 163. 12: 628-633

Kankofer M., Albera E., Feldman M., Gundling N. and Hoedemaker M., 2010. Comparison of antioxidative/ oxidative profiles in blood plasma of cows with and without retained fetal membranes. Theriogenology 74: 13851395

KIZIL O., AKAR Y., YUKSEL M. AND SAAT N., 2010 Oxidative stress in cows with acute puerperal metritis Revue Méd. Vét., 161 (7) 353-357

Koracevic D., Koracevic G. Djordjevic V, Andrejevic S and Cosic V., 2001: Method for the measurement of antioxidant activity in human fluids. J. clin. Pathol. 54, 356-361

Kleczkowski M., Klucinski W., Sikora J., Zdanowigz M., and Dziekan P., 2003. Role of antioxidants in the protection against oxidative stress in cattle- non enzymatic mechanisms (part2). Pol J Vet Sci.6 (4): 301308 (Abstract)

Masella, R., R. Benedetto, R. Vari, C. Filesi and C. Giovannini, 2005. Novel mechanisms of natural antioxidant compounds in biological systems: involvement of glutathione and glutathione-related enzymes. J of Nutritional Biochemistry. 16: 577-586

Nohl, H., L. Gille and K. Stanick, 2005. Intracellular generation of reactive oxygen species by mitochondria. Biochem Phamacol. 69: 719-723

Ohkawa, H., W. Ohishi and K. Yagi, 1979: Assay for lipid peroxides in animal tissues by thiobarbituric acid reaction.Anal biochem.95, 351(2):351-8

Pietro Celi, 2010. Biomarkers of oxidative stress in ruminant medicine. Immunopharmacology and Immunotoxicology: 1-8

Satoch, K., 1978: Serum lipid peroxide in cerebrovascular disorders determined by a new colorimetric method.Clinica chimica Acta, 15; 90(1):37-43.

Tanaka, M., Y. Kamiya, T. Suzuki and Y. Nakai, 2011. Changes in oxidative status in periparturient dairy cows in hot conditions. Animal Science journal, 82, Issue 2: 320-324

Toescu, V., S.L. Nuttall, U. Martin, M.J. Kendall and F. Dunne, 2002. Oxidative stress and normal pregnancy. Clinical Endocrinology, 57: 609-613

Valko, M., M. Izakovic, M. Mazur, C.J. Rhodes and J. Telser, 2004. Role of oxygen radicals in DNA damage and cancer incidence. Mol cell Biochem. 266: 37:56

Yildiz, H., H. Simsik, N. Saat and M. Yuksel, 2011. Effect of dystocia on lipid peroxidation and enzymatic and non enzymatic antioxidants in crossbred dairy cows. Bul. Vet. Inst. Pulawy 55: 135-139

حالة الأكسدة اثناء فترة الحمل المتأخر والولادة وما بعد الولادة حتى الثياع فى الأبقار الفريزيان

د. عبدالجواد خليفة عبدالجواد قادوم و د. محمود عبد الغنى احمد الحناوى

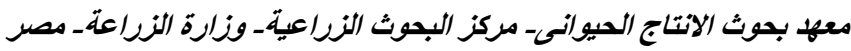

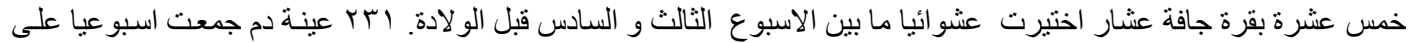

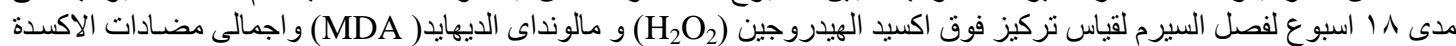

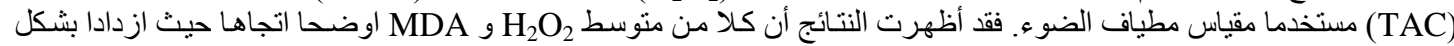

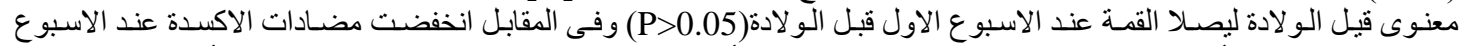

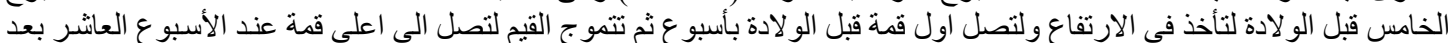

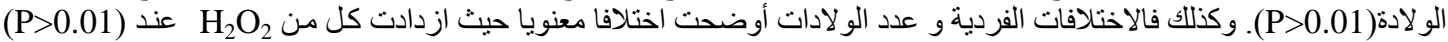

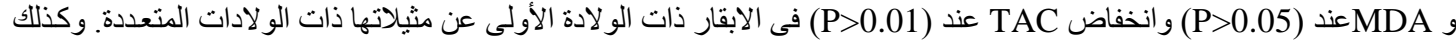

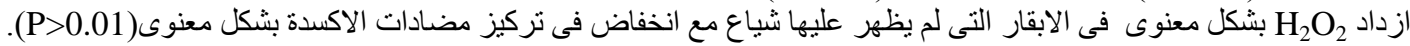

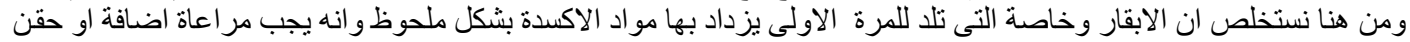
مضادات الاكسدة فى الفترة ما قبل الو لادة بأسبو عين و التنى ربما تساعد على تجاوز مثل هذه الانضغاطات. 